\title{
CEO incentives in European energy utilities: evidence from regulated versus unregulated firms
}

\author{
Carlo Cambini ${ }^{1,2}$ - Sara De Masi ${ }^{3,4}$. \\ Laura Rondi ${ }^{1,5}$
}

Received: 24 July 2015/Revised: 5 January 2016/Accepted: 11 January 2016/

Published online: 25 January 2016

(C) Associazione Amici di Economia e Politica Industriale 2016

\begin{abstract}
This paper studies the effect of incentive mechanisms provided by economic regulation and $\mathrm{CEO}$ compensation in European energy firms. We investigate the differences in CEO pay-for-performance sensitivity across regulated and unregulated firms on CEO monetary incentives. Using various measures of firm performance, we find that CEO pay-for-performance sensitivity is lower in regulated companies. These results hold when we control for national corporate governance variables (investor protection, legal origin, disclosure requirements and contract enforcement). Our findings suggest that incentive compensation is a weaker incentive mechanism for firms operating in regulated and less-competitive markets.
\end{abstract}

Keywords Corporate governance - CEO compensation - Pay-for-performance sensitivity $\cdot$ Regulation · European energy utilities

JEL Classification $\quad$ G3 $\cdot$ G38 $\cdot$ J33 $\cdot$ L51

Sara De Masi

sara.demasi@unifi.it

Carlo Cambini

carlo.cambini@polito.it

Laura Rondi

laura.rondi@polito.it

1 Department of Management (DIGEP), Politecnico di Torino, Torino, Italy

2 IEFE-Bocconi University, Milan, Italy

3 Department of Economics and Management, University of Florence, Florence, Italy

4 Kent State University, Florence, Italy

5 CERIS-CNR, Milan, Italy 


\section{Introduction}

Beginning with the seminal work by Jensen and Murphy (1990), CEO compensation and CEO pay-for-performance sensitivity have been one of the most widely studied topics in corporate governance (Shleifer and Vishny 1997; Murphy 1999; Bebchuk and Fried 2004; Frydman and Saks 2010; Fernandes et al. 2013; Cheng et al. 2015). In any firm that separates ownership and control, CEO compensation has been suggested as a possible mechanism to align the CEO's interests with those of the shareholders. When shareholders cannot perfectly monitor a CEO's decisions (or when they are unlikely to know which actions are value maximizing), the CEO is likely to make decisions intended to maximize his own interests rather than those of the shareholders. Pay-for-performance compensation contracts, which link CEO pay to shareholder wealth via performance indicators, can be a powerful way to motivate and induce CEOs to make decisions that maximize shareholders' wealth.

Such pay-for-performance contracts originate internally, with the firm. It is the board of directors which defines the appropriate incentives for management, particularly for the CEO (Tricker 2012). However, incentives for CEOs may also originate externally, from the business environment. Market competition is a powerful mechanism that may influence how CEOs behave. Specifically, in competitive markets CEOs must make decisions that increase firm performance, firm productivity and shareholder wealth to ensure the firm's survival. Competitive markets are expected to provide incentives that mitigate the classical managerial agency problems between managers and shareholders (Hart 1983; Holmström and Tirole 1989; Giroud and Mueller 2010). In non-competitive markets, where the competitive pressure is weaker, managerial slack, conflict of interests and agency problems are more intense.

The impact of regulation on managers' incentives is unclear. Whereas regulation reduces CEOs' discretion, it is also expected to encourage both effort and efficiency. This paper investigates whether pay-performance sensitivity differs between regulated and deregulated segments. In particular, we study the energy industry to analyze CEO incentives and how internal incentives (i.e., pay-for-performance contracts) may interact with external incentives (i.e., the external environment). In this respect, the EU energy industry is a relevant case study because its regulatory reforms were introduced only two decades ago in most of the Member States (except for the UK, where the process began much earlier). We thus provide a case study of the functioning of one important-and costly to the shareholderscorporate governance mechanism when market competition is not fully effective. Our paper also aims to shed more light on the incentive structure of firms that cover a large share, in terms of market capitalization, in the EU equity market.

The energy sector provides an interesting context to study because in its transmission and distribution segments, it is a non-competitive market in which economic regulation continues to play a strong influencing role. On the one hand, economic regulation intervenes by specifying what firms can and cannot do. By limiting CEOs' discretion to make managerial decisions, regulation may weaken the power of CEOs' internal incentives. On the other hand, economic regulation is 
intended to provide additional incentives to invest, innovate and operate that mimic the competitive mechanism. Moreover, energy firms that were previously vertically integrated were either unbundled and incorporated in "new" legal entities subject to different regulatory regimes or unregulated altogether. By providing incentives to firms, regulation may thus power the "external incentive" that motivates CEOs. Overall, the implications of economic regulation for CEO incentives and in turn, for energy utilities' performance, are uncertain. This paper aims to shed light on the interaction between CEOs' internal and external disciplinary mechanisms to understand whether those mechanisms complement or substitute each other in enhancing firm efficiency.

More specifically, we analyze the relationship between CEO pay and firm performance within a sample of European publicly listed energy utilities from 2000 to 2011 , focusing on the differential responses that arise from being subject to regulation (or not). The energy industry provides a perfect setting to study such relationships. In the early 1990s, most European countries introduced a set of liberalization and privatization reforms that profoundly changed the energy sector. Many European countries set up their own national regulatory authorities (NRAs) that regulated distribution and transmission operations in the energy industry, whereas the generation segment was fully liberalized. However, after more than two decades of market reforms, the degree of liberalization remains heterogeneous across countries and the privatization process is largely incomplete. ${ }^{1}$ These different regulatory settings and market conditions provide us with the within-sector heterogeneity that allows us to build a suitable framework to closely study the interaction between the state of regulation and the incentives provided by either firms or the market.

We focus on differences in pay-performance sensitivities across firms regulated by an NRA (such as transmission and distribution operators) and unregulated companies (generation) within the same industry, thus departing from existing studies that typically compare regulated utilities with unregulated manufacturingsector companies (Joskow et al. 1993; Yermack 1995; Palia 2000; Adams and Mehran 2003). This paper also differs from Cambini et al. (2015), who investigate the effect of incentive vs. cost-based regulation. Whereas our previous study analyzed the impact of structural and regulatory changes in the EU's energy industries, this paper focuses on the differences between regulated (i.e., transmission and distribution) and unregulated (i.e., generation) firms. The key aspect of this analysis is the differential effect on managerial compensation that may be generated by the presence of competitive pressure typical of firms operating in deregulated segments of an industry with respect to firms operating in highly regulated segments of that same industry.

We find that CEO compensation in regulated segments is lower and less responsive to variations in firm performance than it is in the unregulated generation segment. This difference can be explained, at least in part, by the different competitive pressures within the different segments of the industry after

\footnotetext{
${ }^{1}$ For a description of the evolution of the institutional setting within EU utilities, see Barontini and Bozzi (2011).
} 
liberalization. Managers of transmission or distribution utilities operate in a less competitive environment, where profitability targets are more or less set-and somewhat guaranteed-by regulators. For this reason, shareholders may be more reluctant to bear the agency costs that are associated with high monetary incentives tied to firm performance. Alternatively, as suggested by Joskow et al. (1996), the regulatory environment may impose political constraints (in other words, a cap) on executive compensation. Specifically, in many regulated utilities, particularly if those controlled by a national or a local government, directors either are politicians or are appointed by politicians who are subject to public pressure. Therefore, to prevent the public from judging executive compensation to be excessive, CEO remuneration is less tied to firm profitability.

Our results survive several robustness checks. In particular, we account for the ownership share held by the state (because many energy firms are still partially owned by the local or national government), for the country-/industry-specific degree of competition and openness in the energy sector, and for within-sample differences across the electricity and gas sectors. Interestingly, we find that executive compensation increases as the industry becomes more competitive and liberalized, and it decreases when a firm is controlled by the state. Next, we consider the multinational structure of many energy companies. Our findings show that for CEOs in multinational firms, pay-for-performance sensitivity does not differ between regulated and unregulated firms, whereas that difference survives and is significant within local energy firms that operate in a single country.

Finally, we also control for the impact of national governance attributes by including country-specific variables for the origin of the legal system, the degree of minority shareholder protection, the efficiency of debt contracts' enforcement and the strength of disclosure requirements. Again, the main result holds, i.e., pay is less sensitive to performance in regulated energy firms.

Our findings for a representative sample of large and highly valued European companies offer insights to financial investors to pay attention not only to remuneration schemes but also to regulatory settings: unregulated companies are more likely to adopt performance-based regimes to incentivize managers than are regulated companies. At the same time, even though multinational firms are subject to ex ante control, they are more similar to unregulated companies than to "local" companies. This implies that exposure to internationalization makes performancebased compensation more likely to be adopted even in a less competitive, regulated environment.

The paper is organized as follows. Section 2 describes the literature review. Section 3 discusses recent reforms and regulatory policies in the European energy industry. Section 4 describes the data and the variables used in the estimation. Section 5 presents the empirical modeling and the testable hypotheses. Section 6 discusses the results of the econometric analysis and Sect. 7 concludes. 


\section{Literature review}

In firms that separate ownership and control, agency costs between shareholders and managers are likely to arise. Specifically, shareholders are interested in having managers make decisions that maximize firm value, whereas managers are typically more concerned with their own wealth and well-being (Jensen and Meckling 1976; Demsetz 1983; Fama and Jensen 1983; Hart et al. 1997). Moreover, information asymmetries make it difficult for shareholders to monitor managers' actions and to understand which investment opportunities could maximize their wealth. To alleviate these typical principal-agent problems and to align shareholders and managers' interests, scholars and practitioners have considered several corporate governance mechanisms (Agrawal and Knoeber 1996; Shleifer and Vishny 1997). Among others, compensation policies that tie CEO welfare to shareholder wealth can be a powerful tool to decrease agency costs and discourage opportunistic behaviors by managers. $^{2}$

The structure of CEO compensation and pay-for-performance sensitivity play a special role within a company. Early studies such as Murphy (1985), Gibbons and Murphy (1990), and Jensen and Murphy (1990), document the relationship between CEO pay and corporate performance. They argue that when CEO compensation depends on firm results, CEOs will benefit from firm value-maximizing decisions. Therefore, in the absence of strong board mechanisms that can monitor the internal decision-making process, firms may benefit from using either stock-based or accounting indicators or both as performance measures to link executive compensation to performance (Bushman et al. 1996; Fernandes et al. 2013).

Most of this vast empirical literature focuses on US companies (among others, Hall and Liebman 1998; Guay 1999; Frydman 2009; Frydman and Saks 2010). These studies find the predicted positive relationship between executive compensation and firm performance in US companies and they highlight the relevance of compensation contracts in providing incentives for CEOs.

In Europe, the evidence on executive compensation is more recent. One interesting early study on international differences in executive compensation is that of Abowd and Bognanno (1995). They show that in the US, managerial pay is higher and more sensitive to both firm size and long-term compensation plans such as stock options than in European countries. Conyon et al. (2013) and Conyon and Murphy (2000) show that CEO pay is more tightly linked to performance in the US than throughout most of Europe and that American executives hold more wealth in company stock and options than do their European counterparts. One comparative study on executive compensation in countries with mandated pay disclosures is that of Fernandes et al. (2013), who show that US CEOs receive a higher fraction of their compensation in the form of stock and options and they earn an average of $26 \%$ more than their foreign counterparts. Looking at only European companies, Muslu (2010) studies the effect of the board composition on CEO compensation. He provides evidence that for the largest 158 companies in Germany, France and the UK, the sensitivity of executive pay-for-performance increases with the proportion

\footnotetext{
${ }^{2}$ For comprehensive surveys, see Murphy (1999), Goergen and Renneboog (2011) and Murphy (2012).
} 
of executives on the board and with a dual CEO/chairman. Croci et al. (2012) show that in continental Europe, differences in the level of CEO compensation depend on a corporation's ownership structure.

Another stream of the research focuses on CEO compensation and market competition as an important condition for the severity of the agency problem (Hart 1983; Hermalin 1992; Bertrand and Mullainathan 2003; Giroud and Mueller 2010; Beiner et al. 2011). These papers show that product market competition encourages managerial efforts while disciplining managerial slack. By pushing managers to be efficient, such competition may even render additional incentives redundant (Schmidt 1997). In line with this reasoning, Nickell (1996) and Giroud and Mueller (2010) find that industry competition can be an effective substitute for other governance mechanisms.

The literature on executive compensation in non-competitive and more generally, regulated sectors is less abundant and primarily relates to the financial industry. By constraining firms' activities, regulation alters the internal incentives that result from standard market-based mechanism. Hubbard and Palia (1995), Booth et al. (2002), Becher and Frye (2011) and Adams and Ferreira (2012) argue that in the bank industry, the threat of regulatory scrutiny and corrective actions can pressure regulated firms to adopt effective corporate governance monitoring systems.

Within regulated firms, there is even less empirical evidence on public utilities. Because of the particular features of this industry, managers may behave differently and therefore need different forms of incentives. Carroll and Ciscel (1982) and Murphy (1999) analyze compensation in several industries in the US, documenting that the variable portion of a CEO's annual pay is less important in the context of utility firms. Comparing regulated and unregulated companies, Joskow et al. (1993) find that the CEOs of economically regulated US firms earn significantly less than the CEOs of unregulated firms. They argue that this difference reflects, at least in part, the political constraints on CEO compensation imposed, directly and indirectly, by the regulated environment in which the firms operate. According to their view, regulators are reluctant to allow compensation levels that the public might judge to be excessive and as a result, they are reluctant to tie CEO compensation to firm profitability. Yermack (1995) compares US regulated and unregulated firms, showing that US executives in banking, insurance and utilities receive lower incentives from compensation or equity ownership than in unregulated industries. This is probably because the reduced managerial discretion in these industries diminishes the consequences of good or bad decisions. Thus, regulation generates more pressure to limit standard pay-for-performance schemes. Palia (2000) conducts a study on the differences in compensation schemes during the deregulation process in the US utility sector, finding that CEOs in utilities have less pay-performance sensitivity than CEOs operating in manufacturing firms and that after deregulation, pay-performance sensitivity is higher in the utilities.

Whereas the majority of existing studies address regulated companies in the US, the empirical evidence on CEO pay-performance for European energy utilities is very scant. Most of this research focuses more on board composition and 
governance than on CEO pay-for-performance sensitivity (Bender 2003). A recent study by Cambini et al. (2015) investigates CEO pay-for-performance differences across alternative regulatory regimes in the European energy utilities. They find that managerial compensation is sensitive to performance only if is subject to incentive regulation, such as price-cap regulation or benchmarking. They also document that incentive regulation makes managerial entrenchment less likely.

\section{Regulatory policy and privatization reforms in the European Energy Industry: an institutional background}

In the European utility industry, the degree of liberalization is heterogeneous across countries and the privatization process remains incomplete (Bortolotti et al. 2011). From a model largely characterized by vertical integration, state monopolies and public ownership, the sector has been gradually liberalized and vertically unbundled. The energy industry has thus evolved into an industrial organization with more degrees of market opening (in the generation and retailing segments), easier access to essential facilities and private investors' involvement in the ownership of assets as many energy firms were taken public. Substantial progress has been made towards the creation of a single market for energy utilities in Europe, even if individual countries' market structures are not yet converging towards a single, uniform pattern.

The UK was the laboratory for the first large-scale structural reform experiment in the energy utility sector. The approach taken by the European Commission when liberalizing the Member States' energy sectors considered previous experiences, particularly in the UK, which ultimately led to a strong vertical and horizontal deintegration of the industry combined with solid regulation.

Beginning in 1988, the regulatory problem was addressed through a series of measures and directives that established a common de minimis legal framework among the Member States, which were called to transpose those measures and directives into their national laws. In the attempt to construct an internal energy market for the electricity and gas sectors, the two milestone EU Directives are 96/92 and 98/30 for the electricity and gas markets, respectively (Cambini and Rondi 2010). Their purpose was both to gradually introduce competition in generation/ production and to unbundle the various segments in the energy value chain. To achieve this goal, Network System Operators were established as entities carrying out specific system functions, by creating a level playing field for access to transmission and distribution networks, and by forcing the unbundling of vertically integrated operators (the incumbents), at leasSt at the accounting level.

The two Directives also established national regulatory authorities (NRA). ${ }^{3}$ Initially, the new regulatory bodies were simply granted powers to settle disputes among operators and were only required to be independent from the parties involved. In time, the European Commission (EC) legislation broadened the NRAs' powers to ensure/enforce non-discrimination, effective competition, the unbundling

\footnotetext{
3 Art. 20 Directive 96/92/EC and art. 21 of Directive 98/30/EC.
} 
of operations and ultimately, the implementation of incentive regulation regimes to boost firm efficiency. ${ }^{4}$

The third energy package, Directive 2009/72/EC, further increased the unbundling requirements. Now, EU Member States can choose one of three unbundling models: ownership unbundling, an independent system operator or an independent transmission operator. Although the effects of the various unbundling methods are still under discussion, most countries have already switched to ownership unbundling.

With respect to firm ownership, from the beginning, EC Directives did not provide any recommendation about the ownership structure of public utilities in liberalized markets, leaving the privatization decision completely in the hands of national governments. As of 2013, privatization of EU energy firms is far from complete, and central and local governments still hold majority or minority ownership stakes in many regulated utilities, particularly in Austria, France, Finland, Germany and Italy (see Cambini et al. 2012).

Because of these liberalization and privatization reforms, energy utilities underwent a deep change: many went public, opening their capital both to new investors and to various categories of shareholders that naturally aim to maximize firm value. However, although these firms are now public and have modified their behaviors and goals accordingly, embracing shareholders' view more than before, the maximization of shareholder value is not their only consideration. Energy utilities remain firms that provide services of general interest and, as mentioned above, they continue to operate in a regulated environment that imposes constraints on their behavior and their governance. In this new framework, the net effect of CEOs' regulatory incentives and governance mechanisms typical of public equity markets is unclear and is worth analyzing in the context of European energy utilities.

\section{The sample}

Because of liberalization and privatization reforms in the early 1990s, most European countries regulate distribution and transmission activities in the energy industry. Electric and gas utilities, most of which were once fully integrated state monopolies, underwent a profound change: many companies unbundled their generation, transmission and distribution activities and went public, opening their capital to new investors and different categories of shareholders that naturally aim to maximize firm value. To test the interaction between regulation and governance mechanisms, we use a sample of 59 listed public utilities in the energy industry (electricity and gas) from 12 European countries (Spain, France, UK, Germany, Italy, Austria, Switzerland, Norway, Poland, Portugal, Finland and Belgium) over the period 2000-2011. To select these companies, we started from the sample of firms in the "Energy" sector of the Worldscope database (the main source of our accounting data). Next, we checked whether these companies are classified as energy firms in the "Utilities" sector of the stock exchange in which they are traded. We then excluded all companies belonging to the "Industrial" sector of their

\footnotetext{
${ }^{4}$ Art. 23 Directive 2003/54 and Art. 25 Directive 2003/55.
} 
exchange because their primary activity is primarily related to the construction of energy plants or equipment, such as solar panels or collectors, wind towers and so forth, not to the provision of energy services. Finally, we select energy firms that both locate their primary operations in a European country and (obviously) report CEO compensation data. Although our sample may seem small, it is highly representative in that it covers an average of approximately $90 \%$ of total market capitalization of the largest publicly listed energy operators in Europe that meet the above requirements. Among the 59 energy utilities in our sample, 43 transmission and distribution operators are subject to regulation, whereas 16 companies operate in the deregulated energy generation segment.

Data are collected from different sources. Data about CEO compensation and tenure are hand collected; each company's annual corporate governance reports are downloaded. This collection process makes the dataset unique. Our data on CEO compensation are carefully divided into salaries and annual bonuses. A comprehensive measure of CEO pay should consider the values of the CEO's stock and option holdings, but these data were not available for all firms on a consistent basis. Specifically, when we tried to collect the data we found that for most of the European energy utilities, information about the use of stock options and a detailed description of individual CEOs' stock option plans (i.e., the number of options, the exercise price, the exercise date etc.) are not fully disclosed. Because we could only rely on a partial, approximate picture of the real effect of stock options, we decided that adding this partial information would only lead to misleading results. Following Jensen and Murphy (1990), we thus calculate CEO compensation as the sum between salary and bonus awarded by the CEO in a year.

Financial and accounting data come from Datastream-Worldscope and Compustat Global database. Datastream-Worldscope is a global financial database that covers equities, stock market measures and company fundamentals. Compustat Global consists of the annual and quarterly report data for listed companies. It provides complete information about income statements and balance sheets of non-US companies. From these sources, we obtained the variables to calculate both book- and market-based measures of performance. We thus use the ratio of EBIT to total assets, called ROA, as a measure of accounting profitability. Although ROA is not a perfect measure, it is one of the most effective measures to assess company performance. It captures the fundamentals of business performance, looking at both income statement performance and the assets required to run a business. Because this ratio is based on the book value of assets and not on the market value, as market-based indicators we use Stockret (stock return, i.e., the one-year stock return for the firm over its fiscal year) and MarketCap (market capitalization, i.e., the product between the share price at the end of the year and the number of outstanding shares in the market).

One key variable in this study is regulation. Regulatory status varies across countries, across the energy industry's segments and between the electric power and gas sectors. Following the reform process in the European energy sector, we define a firm as regulated or de(un)regulated based on its primary activity (transmission and distribution versus generation and retailing in electricity and gas service, respectively). Typically, firms classified as generators produce energy from primary or renewable resources. Generation companies are typically very large, publicly 
traded, and not subject to regulation, whereas retailers are usually small and unlisted and thus, do not qualify for inclusion in our dataset. In our sample, companies that generate electricity and/or gas are classified as unregulated, whereas companies operating in the transmission and distribution segments are classified as regulated. Finally, when we inspected each company's business activity, we allocate each company to the unregulated or regulated subsample according to its main revenue source. For example, we noticed that a few distributors are also involved in generation; accordingly, in this case we classified firms according to their largest activity based on the information available in the annual reports. In Appendix 1, we provide a list of the energy firms in our sample by country and regulatory status.

To test the robustness of our results, we consider three main potential sources of influence: firm ownership, the actual extent of market liberalization and reforms and stock market development. We thus collected information about the ownership status of each firm in the sample. In particular, we define firms as "privately controlled" if the state holds (either directly or indirectly) less than $30 \%$ of the firm's control rights (i.e., if private investors hold at least $70 \%$ of the control rights). To measure the state's ultimate control rights (UCR), we use the weakestlink approach (see, e.g., La Porta et al. 1999). According to this approach, the UCRs of a given investor (the state in our case) are equal to the minimum ownership stake along a chain (i.e., the weakest link). In the case of multiple chains, the UCR are summed across all chains. ${ }^{5}$

The various paces and intensity of liberalization that characterizes the energy industries in various countries may also affect incentive compensation schemes. To control for this additional effect, we use the OECD index of the Product Market Regulation database by Conway and Nicoletti (2006). This index is an average of several indicators varying from 0 to 6 (lower numbers indicate a greater degree of market openness) and allows for entry barriers, the vertical structure of the market, the market share of the dominant player(s), ${ }^{6}$ and the presence of the state as a shareholder. We eliminate the state ownership component from the index because we have already constructed a "firm-by-firm" ownership dummy (instead of using a sectoral-level variable) and recalculate the average over the remaining OECD subindicators (market entry, vertical integration and market structure). As in the original OECD index, high index values are associated with low degrees of market competition and liberalization.

Finally, to control for the impact of national governance attributes, we use a set of country-level variables (see, e.g., Aslan and Kumar 2014). To capture the crosscountry differences in the area of investor and property-rights protection, we use a dummy variable, Common Law, which is equal to 1 if the country's legal origin is the common law (versus the civil law) (La Porta et al. 1999). To account for efficiency in the enforcement of contracts and the quality of disclosure

\footnotetext{
5 Here we implement the same methodology as in Barontini and Bozzi (2011). We merged ownership information from that database (ranging from 1994 to 2005) and then completed the data up to 2010 with hand-collected information from companies' Websites.

${ }^{6}$ Low values of the entry-barrier indicators are associated with competition in all segments of the relevant sector and with vertical separation between downstream and upstream firms. High values are associated with the existence of a vertically integrated legal monopoly.
} 
requirements, we use, Enforcement Index (Djankov et al. 2008) and Disclosure Index (La Porta et al. 1999). We then include two time-varying variables to control for economic development $(G D P)$ and stock-market development measured as the ratio between market capitalization and GDP (MarketCap_GDP).

Table 1 provides the variable definitions and Table 2 reports the summary statistics for the full sample. In Table 3, we report the descriptive statistics for the regulated and unregulated subsamples and the results of simple tests of mean differences. In Appendix 2, we report the data by country.

At the country level, CEO compensation appears to be highest in Germany and Spain; however, we also note that firms in these countries are very large, confirming the typically positive correlation between pay and firm size (Baker and Hall 2004). Managers seem to be well paid in Finland, Austria and (to a lesser extent) Italy, where firms are not only quite large but also profitable in terms of ROA. Interestingly, we observe that although firm accounting profitability seems to be higher in the UK than in any other country, UK energy managers appear to be paid less than average, although they achieve the highest profitability levels. In Table 3, we find several interesting differences as we note that compared to unregulated energy utilities, regulated firms are (on average) larger and more state controlled, but they pay their managers more (the evidence on profitability is mixed and statistically insignificant). Moreover, and unsurprisingly, the average OECD indexes show that regulated firms operate in less open and liberalized segments. Finally, the share of regulated firms is higher in countries where shareholder protection is weaker and financial markets are less developed.

Clearly, the descriptive statistics not only highlight several intriguing differences but also reveal that too many factors should be considered. Therefore, in the following section, we turn to the results from the regression analysis.

\section{Empirical approach}

This paper's main purpose is to determine how the incentives provided by CEO compensation interrelate with the incentives provided by economic regulation. We focus on the energy industry. By looking at a single industry's CEOs, who therefore have tasks, required expertise and attributes that are relatively similar (compared to other manufacturing sectors), we can more effectively isolate the effect of the various regulatory frameworks on the relationship between pay and performance. Because, electric and gas utilities might rely on different types of corporate governance mechanisms to some extent, we also estimate their pay-for-performance sensitivity separately.

\subsection{Measuring pay-performance sensitivity}

Pay-performance sensitivity is the relationship that reveals the presence of incentive compensation contractual schemes. It is usually defined as a change in CEO pay associated with a change in firm performance (Frydman and Saks 2010; Goergen 
Table 1 Variables description

\begin{tabular}{|c|c|c|c|}
\hline Variable name & Label & Description & Source \\
\hline CEO comp & CEO compensation & $\begin{array}{l}\text { It is computed as the sum between salary and } \\
\text { bonus awarded by CEOs at the end of the } \\
\text { year. (Thousands of Euros) }\end{array}$ & Hand collected \\
\hline Stock Return & Stock Return & $\begin{array}{l}\text { It is calculated using prices from end-of- } \\
\text { period to end-of-period (fiscal year). } \\
\mathrm{r}(\mathrm{t})=\left\{\left[\mathrm{p}(\mathrm{t}) \mathrm{f}(\mathrm{t}) / \mathrm{p}\left(\mathrm{t}^{\prime}\right)\right]-1\right\} \text { where } \mathrm{p}(\mathrm{t}) \text { is the } \\
\text { sale price or closing bid at time } \mathrm{t}, \mathrm{f}(\mathrm{t}) \text { is the } \\
\text { factor to adjust price by splits and dividends } \\
\text { in period } \mathrm{t} \text {; } \mathrm{p}(\mathrm{t} \text { ') is the sale price or closing } \\
\text { bid at the previous period }\end{array}$ & Worldscope \\
\hline ROA & Return on Assets & $\begin{array}{l}\text { It is calculated as: (Net Income before } \\
\text { Preferred Dividends }+((\text { Interest Expense } \\
\text { on Debt-Interest Capitalized }) \times(1-\text { Tax } \\
\text { Rate })) \text { /Average of Last Year's and Current } \\
\text { Year's Total Assets } \times 100\end{array}$ & Worldscope \\
\hline Market Cap & $\begin{array}{l}\text { Market } \\
\text { capitalization }\end{array}$ & $\begin{array}{l}\text { It is Market Price-Fiscal Period } \\
\text { End } \times \text { Common Shares Outstanding }\end{array}$ & Worldscope \\
\hline $\begin{array}{l}\text { Log (Total } \\
\text { Asset) }\end{array}$ & $\begin{array}{l}\text { Logarithm of Total } \\
\text { Assets }\end{array}$ & $\begin{array}{l}\text { It is the logarithmic transformation (base 10) } \\
\text { of Total Assets }\end{array}$ & Worldscope \\
\hline Tenure & CEO tenure & $\begin{array}{l}\text { It indicates the number of years served as } \\
\text { CEO }\end{array}$ & Datastream \\
\hline REG & Regulation & $\begin{array}{l}\text { It is a dummy that assumes } 1 \text { if the firm is } \\
\text { under regulation. }\end{array}$ & $\begin{array}{l}\text { Company } \\
\text { websites }\end{array}$ \\
\hline $\begin{array}{l}\text { State } \\
\text { Ownership }\end{array}$ & $\begin{array}{l}\text { Government control } \\
\text { rights }\end{array}$ & $\begin{array}{l}\text { It is a dummy that assumes } 1 \text { if the } \\
\text { government holds at least } 30 \% \text { of the } \\
\text { ultimate control rights }\end{array}$ & $\begin{array}{l}\text { Company } \\
\text { websites }\end{array}$ \\
\hline $\begin{array}{r}\text { OECD Index of } \\
\text { Liberalization }\end{array}$ & $\begin{array}{l}\text { Index of market } \\
\text { competition }\end{array}$ & $\begin{array}{l}\text { It ranges from } 0 \text { to } 6 \text {. A high value is } \\
\text { associated with a low degree of market } \\
\text { competition and liberalization }\end{array}$ & OECD \\
\hline $\begin{array}{l}\text { Market Cap/ } \\
\text { GDP }\end{array}$ & $\begin{array}{l}\text { Total stock market } \\
\text { capitalization } \\
\text { over GDP }\end{array}$ & $\begin{array}{l}\text { It is the ratio of the total market capitalization } \\
\text { and GDP in a country in a given year }\end{array}$ & OECD \\
\hline $\begin{array}{l}\text { Shareholder } \\
\text { Protection }\end{array}$ & $\begin{array}{l}\text { Index of minority } \\
\text { shareholder } \\
\text { protection }\end{array}$ & $\begin{array}{l}\text { It ranges from } 0 \text { to } 27 \text {. A high value is } \\
\text { associated with a stronger level of } \\
\text { shareholder protection }\end{array}$ & $\begin{array}{l}\text { Martynova and } \\
\text { Renneboog } \\
(2011)\end{array}$ \\
\hline Legal Origin & Legal Origin & $\begin{array}{l}\text { It is a dummy that assumes } 1 \text { if the legal } \\
\text { origin is common law and } 0 \text { otherwise }\end{array}$ & $\begin{array}{l}\text { Aslan and } \\
\text { Kumar } \\
(2014)\end{array}$ \\
\hline Anti Director & $\begin{array}{l}\text { Index of } \\
\text { shareholder } \\
\text { protection }\end{array}$ & $\begin{array}{l}\text { It measures the extent of minority shareholder } \\
\text { protection and ranges from } 0 \text { to } 7 \text { as } \\
\text { shareholders' rights protection increases }\end{array}$ & $\begin{array}{l}\text { Aslan and } \\
\text { Kumar } \\
(2014)\end{array}$ \\
\hline $\begin{array}{l}\text { Enforcement } \\
\text { Index }\end{array}$ & $\begin{array}{l}\text { Index of debt } \\
\text { enforcement }\end{array}$ & $\begin{array}{l}\text { It measures the efficiency of debt enforcement } \\
\text { and is equal to the estimated average } \\
\text { duration (years) from the declaration of } \\
\text { default to the time of debtor payment }\end{array}$ & $\begin{array}{l}\text { Aslan and } \\
\text { Kumar } \\
(2014)\end{array}$ \\
\hline $\begin{array}{l}\text { Disclosure } \\
\text { Index }\end{array}$ & $\begin{array}{l}\text { Index of } \\
\text { information } \\
\text { disclosure } \\
\text { requirements }\end{array}$ & $\begin{array}{l}\text { It measures the strength of national disclosure } \\
\text { regulations }\end{array}$ & $\begin{array}{l}\text { Aslan and } \\
\text { Kumar } \\
(2014)\end{array}$ \\
\hline
\end{tabular}


Table 2 Descriptive statistics (full sample)

\begin{tabular}{lcllll}
\hline Variable & Obs & Mean & SD & Min & Max \\
\hline CEO compensation & 418 & 1262.67 & 1491.03 & 114.04 & $11,640.74$ \\
Stock Return & 492 & 0.08 & 0.38 & -1 & 1.89 \\
ROA (\%) & 535 & 6.90 & 7.03 & -42.09 & 79.09 \\
Market capitalization & 485 & $1.36 \times 10^{7}$ & $2.27 \times 10^{7}$ & 4503.35 & $2.10 \times 10^{8}$ \\
Log (Total Asset) & 580 & 15.47 & 2.23 & 4.66 & 19.23 \\
CEO Tenure & 520 & 3.71 & 2.39 & 1 & 12 \\
State Ownership & 674 & 0.55 & 0.50 & 0 & 1 \\
OECD Index of Liberalization & 674 & 1.46 & 1.63 & 0 & 6 \\
Market Cap/GDP & 656 & 89.65 & 60.08 & 12.79 & 309.45 \\
Corporate Governance country level controls & & & & \\
Shareholder Protection & 651 & 19.61 & 4.62 & 11 & 26 \\
Common Law & 548 & 0.32 & 0.47 & 0 & 1 \\
Anti Director & 548 & 4.05 & 0.72 & 2.5 & 5 \\
Enforcement Index & 548 & 5.83 & 0.86 & 4.46 & 7.23 \\
Disclosure Index & 548 & 0.66 & 0.14 & 0.42 & 0.83 \\
\hline
\end{tabular}

Notes: CEO compensations, Market capitalization and Total Assets are in Thousands of 2005 constant Euros

Table 3 Descriptive statistics regulated vs. unregulated firms

\begin{tabular}{|c|c|c|c|c|c|c|c|}
\hline \multirow[t]{2}{*}{ Variable } & \multicolumn{3}{|c|}{$\begin{array}{l}\text { Regulated segments (TSO, } \\
\text { DSO) }\end{array}$} & \multicolumn{3}{|c|}{$\begin{array}{l}\text { Deregulated segment } \\
\text { (Generation) }\end{array}$} & \multirow{2}{*}{$\begin{array}{l}\text { Diff. } \\
t\end{array}$} \\
\hline & Obs & Mean & SD & Obs & Mean & $\mathrm{SD}$ & \\
\hline CEO compensation & 321 & 1333.37 & 1638.36 & 97 & 1028.67 & 798.44 & $*$ \\
\hline Stock Return & 396 & 0.09 & 0.35 & 96 & 0.05 & 0.48 & - \\
\hline ROA (\%) & 431 & 6.83 & 4.61 & 104 & 7.21 & 12.95 & - \\
\hline Market capitalization & 386 & $1.35^{*} 10^{7}$ & $2.28 * 10^{7}$ & 99 & $1.42 * 10^{7}$ & $2.24 * 10^{7}$ & - \\
\hline Log (Total Asset) & 450 & 15.85 & 1.69 & 128 & 14.16 & 3.19 & $* * *$ \\
\hline CEO Tenure & 401 & 3.73 & 2.40 & 118 & 3.66 & 2.36 & - \\
\hline State Ownership & 490 & 0.66 & 0.47 & 161 & 0.23 & 0.42 & $* * *$ \\
\hline OECD Index of Liberalization & 490 & 1.58 & 1.74 & 161 & 0.98 & 1.11 & $* * *$ \\
\hline Shareholder Protection & 488 & 19.41 & 4.43 & 161 & 20.23 & 5.16 & $*$ \\
\hline Market Cap/GDP & 490 & 85.12 & 65.44 & 161 & 104.32 & 37.14 & $* * *$ \\
\hline
\end{tabular}

Notes: CEO compensation, Market capitalization and Total Assets are in Thousands of 2005 constant Euros

and Renneboog 2011). The incentive effects of CEO compensation are typically calculated using various metrics and performance variables. In their seminal paper, Jensen and Murphy (1990) define pay-for-performance sensitivity as the dollar change in a CEO's wealth associated with a dollar change in the shareholders' 
wealth. This specification measures the magnitude of the CEO's sensitivity to changes in the firm performance and denotes the CEO's "share" of value creation. A second metric widely used in the literature is the elasticity of pay to firm performance. In this case, both CEO compensation and firm performance are in logarithm form. The regression coefficient is interpreted as the percentage change in the CEO's wealth associated with the percentage change in the wealth of shareholders. The third metric is the semi-elasticity of pay for performance, in which the dependent variable, CEO compensation, is in the logarithmic form and the independent variable, firm performance, is in the linear form. The regression coefficient is the semi-elasticity of CEO compensation with respect to shareholder value (Joskow et al. 1993): it indicates the percentage change in CEO compensation caused by a unit change in the variable that measures firm performance. In each of these three specifications, the higher coefficient is interpreted as a closer alignment of interests between the CEO and his shareholders and as consequence, a stronger incentive for the CEO.

In our models, we calculate the pay-performance semi-elasticity and elasticity to estimate the relationship between CEO pay and firm performance. We rely on three measures of firm performance. The first measure is that of the stock return, which is widely employed in the literature. The stock return indicates appreciation in the stock price plus any dividends paid, divided by the original price, thus providing the yield realized by shareholders. To check the robustness of our results, we test CEO pay-performance sensitivity using another stock-based variable: market capitalization. However, stock market-based variables are influenced by many factors beyond managers' control and for this reason, they may be a noisy measure of performance. Moreover, because public utilities typically provide services of general interest and may be asked to pursue general-purpose and consumer-welfare objectives, it would be somewhat incomplete to rely exclusively on stock market-based measures. Therefore, we also use an accounting-based measure of performance, return on assets, or ROA (EBIT to total assets), which is a measure of profitability that scales how efficiently a firm's assets are employed (see also Hadlock et al. 2002).

To understand the differences in CEO incentives, we focus on differences across industry segments and over time. We thus interact firm performance with a dichotomous variable, REG, which indicates, in each year, whether a company is subject to sectoral regulation. The dummy REG differs depending on whether a firm is an electric or gas transmission or distribution operator and varies yearly, so it allows us to capture changes in pay-performance when the status of the company changes. The first, baseline model is a standard specification that adds CEO tenure, firm size and country GDP. The $i$ subscript indicates company observations, the subscript $t$ is reserved for index time, the subscript $k$ refers to countries and the subscript $j$ refers to the industry (i.e., electricity and gas). For estimation, we rely on the fixed-effect estimator, which allows us to capture all time-invariant characteristics at the firm, industry and country levels. 


$$
\begin{aligned}
\log (\text { CEOcomp })_{i k j t}= & \alpha+\beta_{1}(\text { performance })_{i j k t}+\beta_{2}(\text { performance })_{i j k t} \\
& \times R E G+\beta_{3} \text { tenure }_{i j k t}+\beta_{4} \log (\text { Total asset })_{i j k t}+\beta_{5} G D P_{k t}+\mu_{i}+\epsilon_{i j k t}
\end{aligned}
$$

The second specification adds a set of variables designed to describe the environment in which the studied firms operate. First, as described in Sect. 3, many energy firms are still partially owned by the state, which may affect both the shareholders' monitoring incentives and the managers' behavior (Claessens et al. 2000; Faccio and Lang 2002). We therefore include a dichotomous variable defining the firm as "state-controlled" if the state holds (either directly or indirectly) up to $30 \%$ of the ownership rights. Next, we account for potential sources of influence on pay-for-performance sensitivity caused by industry and country factors, such as the degree of market liberalization-which is expected to introduce more competitive pressure-minority shareholder protection and stock market development, which proxy for the degree of external discipline provided by the financial market. The model is as follows:

$$
\begin{aligned}
& \log (\text { CEOcomp })_{i j k t}=\alpha+\beta_{1}(\text { performance })_{i j k t}+\beta_{2}(\text { performance })_{i t j k} \times R E G \\
& +\beta_{3} \text { tenure }_{i j k t}+\beta_{4} \log (\text { Total asset })_{i j k t}+\beta_{5} \text { StateOwnership }_{i j k t} \\
& +\beta_{6} \text { OECD Index of liberalization }{ }_{j k t}+\beta_{7} \text { Shareholder Protection }_{k t} \\
& +\beta_{8} \text { MarketCap } / G D P_{k t}+\mu_{i}+\epsilon_{i j k t}
\end{aligned}
$$

\subsection{Robustness analysis}

To test the robustness of our results, we perform a sensitivity analysis to control for sectorial specificities and the various degrees of internationalization of the companies in our sample. In addition, because the recent corporate governance literature (Kumar and Zattoni 2013) has focused on the potential influence of national-level variables in understanding how corporate governance mechanisms work, we also test whether the difference in pay-performance across regulatory regimes survives when we introduce these variables in our regressions.

In more detail, to ensure that the empirical analysis (and the results) is not driven by unspecified differences between the electric and gas utilities in the energy industry, we first construct a dummy to identify electric companies and re-estimate model (2) on this subsample.

Second, numerous firms in the dataset have operations in various countries (inside and outside the EU). Because they tap the international capital market for funds, multinational enterprises are likely subject to tighter corporate governance discipline, which may reduce the differences between regulated and unregulated firms. Moreover, multinational enterprises have complex internal organizations and typically enjoy access to a larger, more sophisticated market for managers. Additionally, in recent years some energy companies have merged to expand their businesses abroad. This implies that a firm has merged or acquired another firm to 


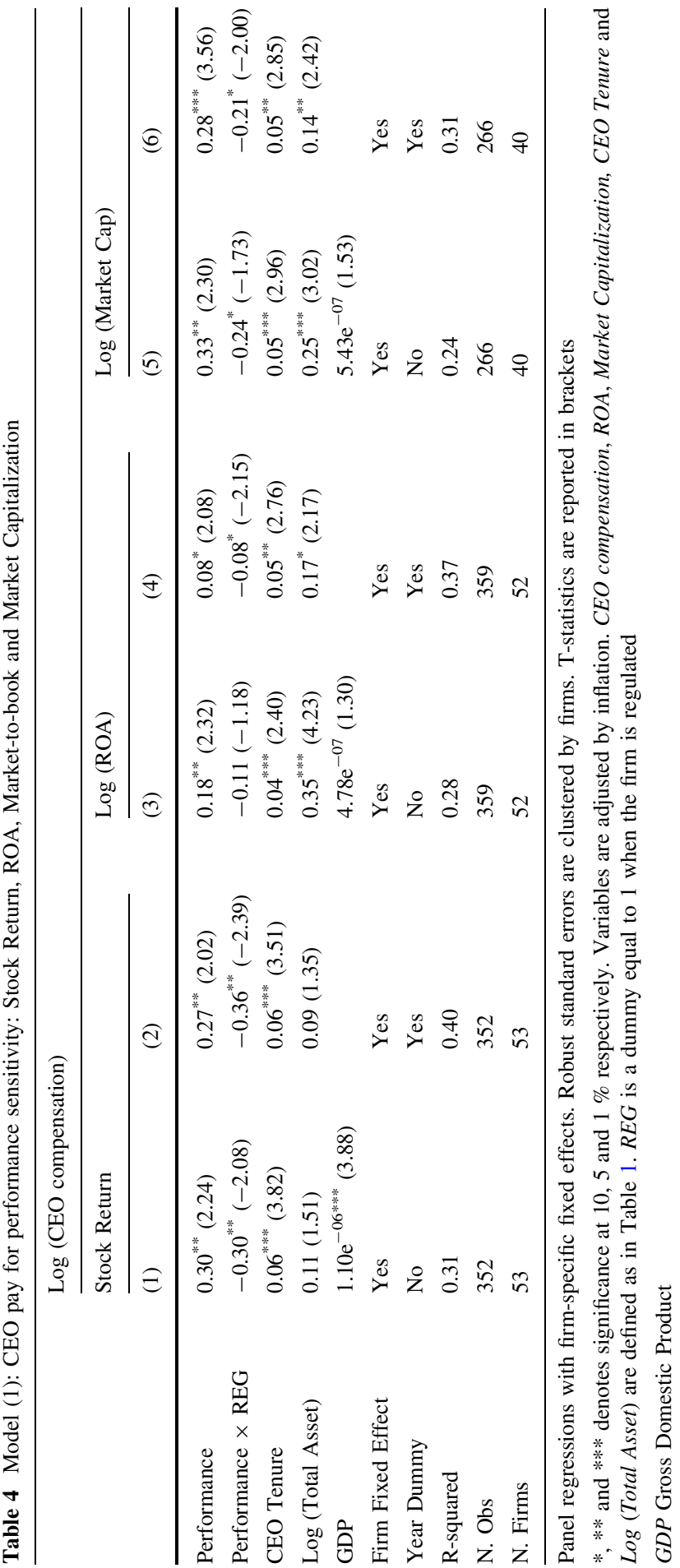


Table 5 Model (2): controlling for Firm Ownership, Market Liberalization and Financial Institutions

\begin{tabular}{llll}
\hline & \multicolumn{2}{l}{ Log (CEO compensation) } \\
\cline { 2 - 4 } & $\begin{array}{l}\text { Stock Return } \\
(1)\end{array}$ & $\begin{array}{l}\text { Log (Market Cap) } \\
(2)\end{array}$ & $\begin{array}{l}\text { Log (ROA) } \\
(3)\end{array}$ \\
\hline Performance & $0.31^{* *}(2.14)$ & $0.36^{* *}(2.61)$ & $0.23^{* * *}(2.89)$ \\
Performance $\times$ REG & $-0.34^{* *}(-2.19)$ & $-0.29^{*}(-1.97)$ & $-0.18^{*}(-1.97)$ \\
CEO Tenure & $0.06^{* * *}(3.24)$ & $0.05^{* * *}(2.86)$ & $0.04^{* *}(2.11)$ \\
Log (Total Asset) & $0.13(1.59)$ & $0.20^{* *}(2.60)$ & $0.29^{* * *}(3.39)$ \\
State Ownership & $-0.31^{*}(-1.65)$ & $-0.31(-1.64)$ & $-0.31(-1.49)$ \\
OECD Index of Liberalization & $-0.12(-1.40)$ & $-0.19^{* * *}(-3.45)$ & $-0.15^{*}(-1.70)$ \\
Shareholder Protection & $-0.01(-0.52)$ & $-0.02^{*}(-1.65)$ & $-0.01(-0.98)$ \\
Market Cap/GDP & $-0.0002(-0.23)$ & $-0.0002(-0.59)$ & $-0.0005(-0.65)$ \\
R-squared & 0.30 & 0.35 & 0.32 \\
N. Obs & 353 & 346 & 360 \\
N. Firms & 54 & 55 & 53 \\
\hline
\end{tabular}

Panel regressions with firm-specific fixed effects Robust standard errors are clustered by firm. T-statistics are reported in brackets

$*$, ** and *** denotes significance at 10,5 and $1 \%$ respectively. Variables are adjusted by inflation. $C E O$ compensation, Stock Return, ROA, Market Capitalization, CEO Tenure and Log (Total Asset) are defined as in Table 1. REG is a dummy equal to 1 when the firm is regulated. State Ownership is a dummy variable that is 1 when the state has at least $30 \%$ the control rights. OECD Index of Liberalization indicates the degree of market competition: a high value of this index is associated with a low degree of market competition and liberalization. Shareholder Protection measures shareholder and creditors' protection, as well as the quality of the law enforcement: a high value is associated with a larger protection of investors and control over CEO performance. Market Cap/GDP is the ratio between total stock market capitalization and the Gross Domestic Product

become an international company. To allow for the potential effect of internationalization on the structure of CEO compensation and to control for merger and acquisition operations, we collected information about each firm's geographical diversification and constructed a time-varying dummy variable that takes a value equal to 1 when a firm has multinational operations. ${ }^{7}$ Because multinational status does not vary over time in the sample period, we use the dummy to separate the sample (similar to the above analysis of the electric firms) and re-estimate model (2) for the two subsamples of multinational and "local" energy firms.

Finally, following Aslan and Kumar (2014), we consider that the national governance system variables may affect the agency costs of dominant shareholders, the efficiency of enforcement of contacts and the quality of information disclosure-and thus, the propensity to adopt incentive compensation schemes. Therefore, in our third model, we add the following country-specific variables: Legal Origin, a dummy variable that is 1 if the country's legal origin is common law (La Porta et al. 1999); Anti Director measures the degree of minority shareholder protection ranging from 0 to 7 ; Enforcement measures the efficiency of debt

\footnotetext{
${ }^{7}$ We thank the anonymous referees for suggesting this further control.
} 
Table 6 Model (2): CEO pay for performance sensitivity for electric companies (subsample)

Log (CEO compensation)

\begin{tabular}{llll}
\cline { 2 - 3 } & $\begin{array}{l}\text { Stock Return } \\
(1)\end{array}$ & $\begin{array}{l}\text { Log (Market Cap) } \\
(2)\end{array}$ & $\begin{array}{l}\text { Log (ROA) } \\
(3)\end{array}$ \\
\hline Performance & $0.35^{* *}(2.30)$ & $0.38^{* * *}(2.59)$ & $0.23^{* *}(2.53)$ \\
Performance $\times$ REG & $-0.33^{* *}(-2.05)$ & $-0.26^{*}(-1.64)$ & $-0.16^{*}(-1.59)$ \\
CEO Tenure & $0.06^{* * *}(2.75)$ & $0.05^{* *}(2.42)$ & $0.04 * *(1.78)$ \\
Log (Total Asset) & $0.24 * *(2.41)$ & $0.24 * * *(2.78)$ & $0.35^{* * *}(3.96)$ \\
State Ownership & $0.06(1.62)$ & $0.12^{* * *(2.57)}$ & $0.10^{* * *}(2.69)$ \\
OECD Index of Liberalization & $-0.06(-0.80)$ & $-0.10^{*}(-1.81)$ & $-0.91(-1.09)$ \\
Market Cap/GDP & $0.00(0.53)$ & $0.00(0.04)$ & $0.00(0.08)$ \\
R-squared & 0.62 & 0.07 & 0.65 \\
N. Obs & 291 & 286 & 297 \\
N. Firms & 45 & 46 & 45 \\
\hline
\end{tabular}

Panel regressions with firm-specific fixed effects Robust standard errors are clustered by firm. T-statistics are reported in brackets

$*$, ** and $* * *$ denotes significance at 10,5 and $1 \%$ respectively. Variables are adjusted by inflation. CEO compensation, Stock Return, ROA, Market Capitalization, CEO Tenure and Log (Total Asset) are defined as in Table 1. REG is a dummy equal to 1 when the firm is regulated. State Ownership is a dummy variable that is 1 when the state has at least $30 \%$ the control rights. OECD Index of Liberalization indicates the degree of market competition: a high value of this index is associated with a low degree of market competition and liberalization. Market Cap/GDP is the ratio between total stock market capitalization and the Gross Domestic Product

contracts' enforcement (Djankov et al. 2008); and Disclosure shows the stringency of disclosure requirements (La Porta et al. 1999). Notably, however, because all of these variables are time invariant and thus perfectly collinear to the fixed firmspecific effect, for estimation, we rely on the generalized least squares random effects model. The specification becomes:

$$
\begin{aligned}
& \log (\text { CEOcomp })_{i j k t} \\
& =\alpha+\beta_{1}(\text { performance })_{i j k t}+\beta_{2}(\text { performance })_{i j k t} \times R E G \\
& +\beta_{3} \text { tenure }_{i j k t}+\beta_{4} \log (\text { Total asset })_{i j k t}+\beta_{5} \text { State Ownership }_{i j k t}
\end{aligned}
$$

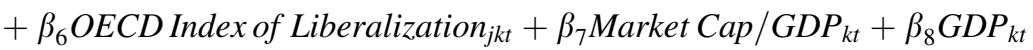

$$
\begin{aligned}
& +\beta_{9} \text { LegalOrigin }_{k t}+\beta_{10} \text { AntiDirector }_{k t}+\beta_{11} \text { Enforcement }_{k t} \\
& +\beta_{12} \text { Disclosure }_{k t}+\mu_{i}+\epsilon_{i j k t}
\end{aligned}
$$

\section{Regulated versus deregulated energy firms: the empirical results}

We start with the results of the baseline model (1) in Table 4 and then proceed with the augmented models in Tables 5, 6, 7 and 8 . 


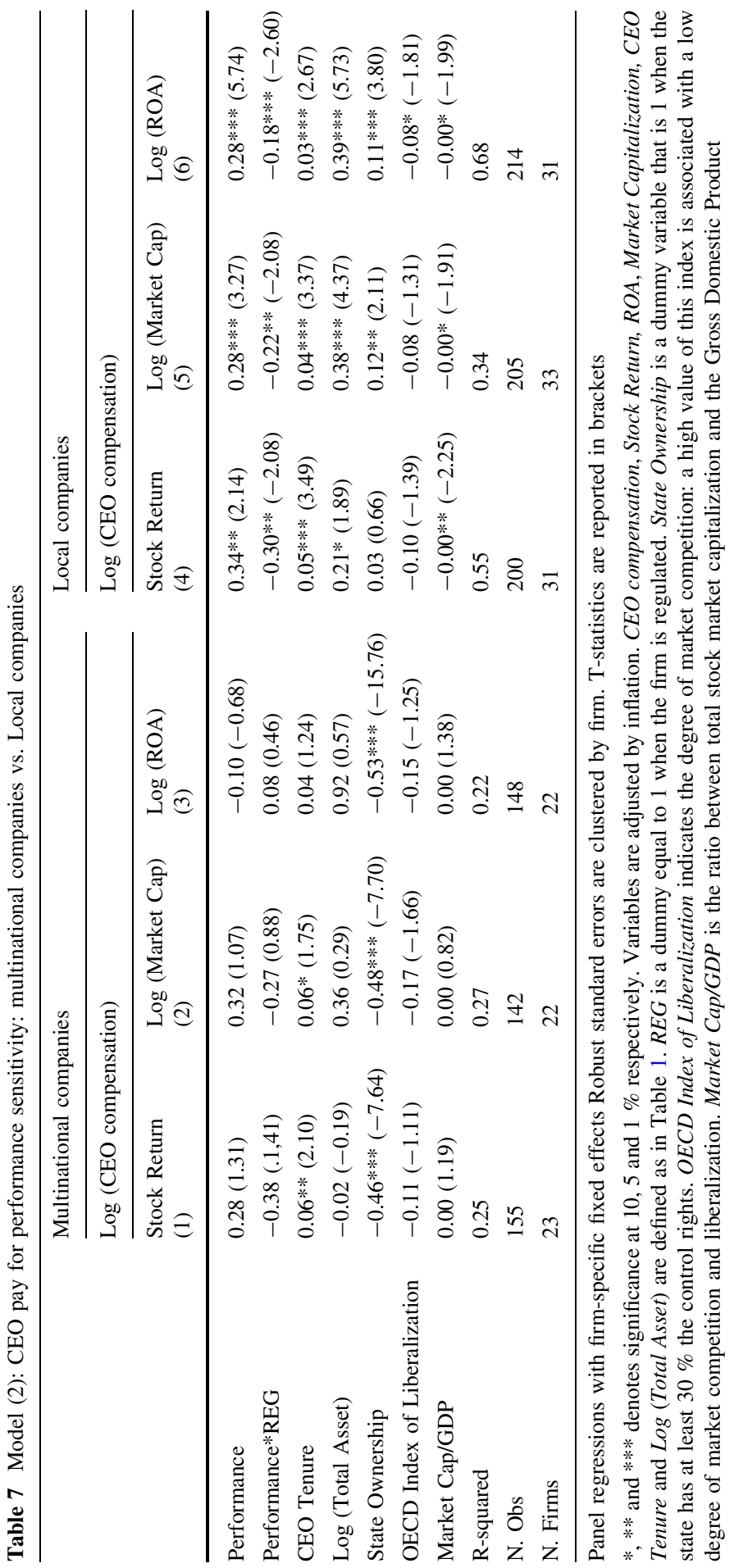




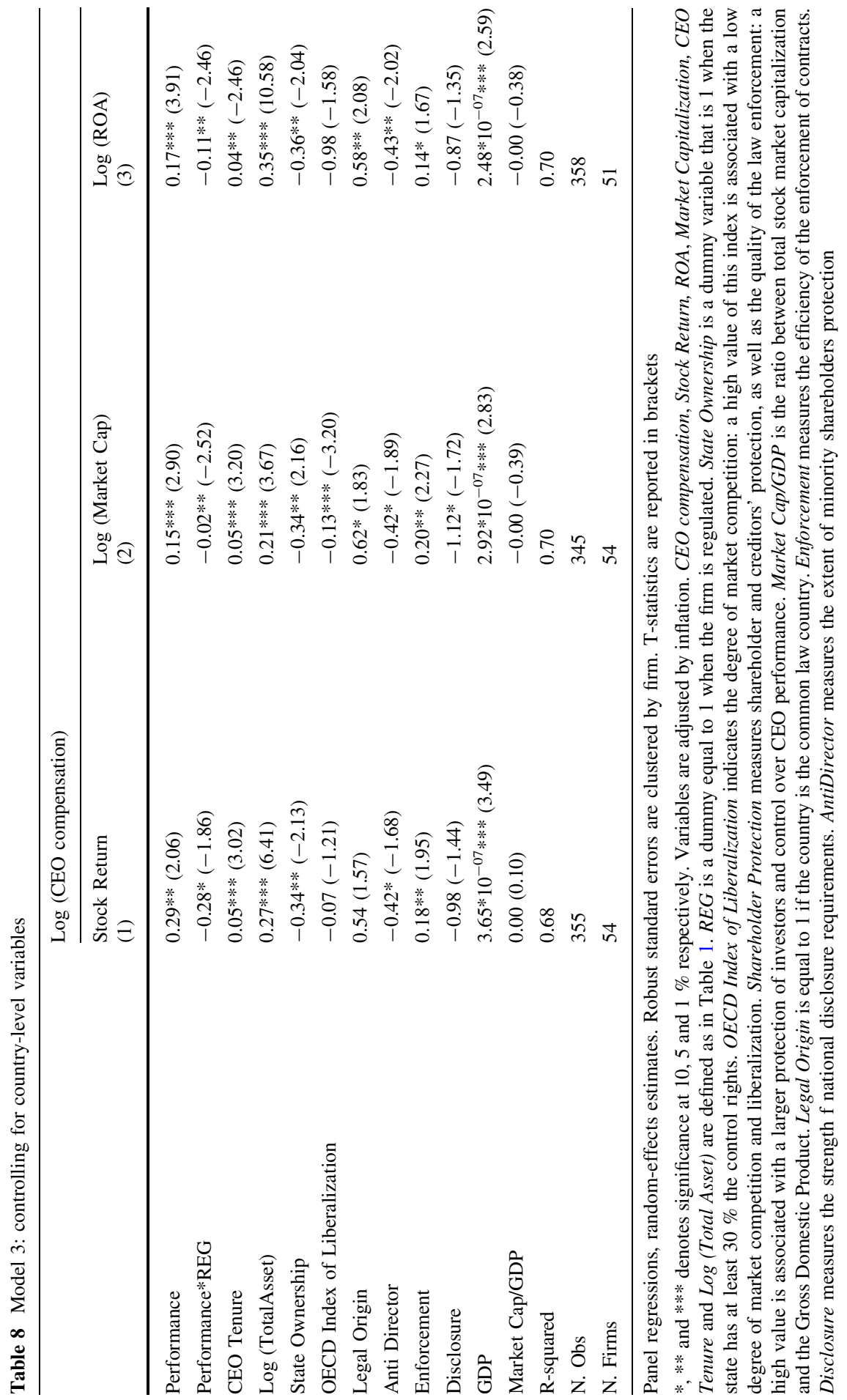


We find that performance terms enter with a positive and significant coefficient in all columns, whereas the interactions with the REG dummy are negatively signed and significant (Table 4). Taken together, these results indicate that pay-performance elasticity in regulated firms is lower than in the subsample of unregulated companies, supporting our hypothesis that regulation constrains CEOs' decisional power to reduce the scope of incentive-compensation contracts. This limited managerial discretion will therefore reduce the consequences of CEOs' decisions, discouraging the adoption of costly corporate governance mechanisms in these segments in which competitive pressure is weaker and possibly allowing managers to "enjoy the quiet life" (Bertrand and Mullainathan 2003); this is also confirmed by the significantly larger compensation received by regulated CEOs. Finally, this result is also consistent with Joskow et al. (1996), who explain that the lower sensitivity reflects the political constraints on CEO compensation imposed (whether directly or indirectly) by the regulated environment. Because of a politically motivated "moral suasion", CEO compensation in regulated companies would voluntarily be less tied to firm profitability. If we look at control variables, we find that CEO tenure and firm size enter with positive and significant coefficients, as expected. It is only in Columns (1) and (2) that firm size is not statistically significant. Overall, the evidence in Table 4 suggests a significant difference in the pay-performance sensitivity of unregulated and regulated energy firms in the EU.

Our second model takes into account differences in firm ownership, market liberalization, shareholder protection and stock market development. In statecontrolled firms, CEOs are expected to receive lower compensation to avoid fomenting dissent among the public. Conversely, a higher level of financial development and market liberalization may positively influence the propensity to rely on incentive compensation. The regressions in Table 5 control for these factors and the results show that the key findings hold: in transmission- and distributionregulated firms, CEO compensation is significantly less responsive to variations in firm performance than in the unregulated generation segment. The OECD Index of Liberalization is negative and statistically significant in most columns. The negative sign suggests that in more liberalized markets, CEOs receive higher compensation. The variable State Ownership is negative and statistically significant in Column (1), indicating that CEO compensation is lower in state-controlled firms as predicted by Joskow et al. (1993). Shareholder Protection has a negative coefficient (significant in Column (2)), showing that CEO compensation is lower in countries where the law provides stronger investor protection, a result that is in line with the predictions of the law and finance literature. Finally, we report no significant evidence that the development of the stock market affects the level of CEO compensation in the energy sector.

Our sample of energy firms includes both electric and gas utilities, which might differ to some extent in terms of managerial practices and monitoring techniques in spite of the fact that they both operate in the energy market. Therefore, to control for the fact that the above differences in pay-performance sensitivity between regulated and unregulated firms are not driven by unspecified cross-sector differences, we test the model for the subsample of electric companies (Table 6). Comfortingly, the results both support and confirm the evidence of lower elasticity of pay to 
performance within regulated electric firms. The performance term is positive and statistically significant in all of the columns, and the interactions with the REG dummy remain negative and significant. ${ }^{8}$ CEO tenure and Log Total Assets remain positive and statistically significant, confirming that within electric companies, CEO compensation increases with the number of years served and as the company becomes bigger. Interestingly, however, we find that state ownership enters with a positive sign, suggesting that CEOs in state-controlled electric companies are paid more.

As a further control, we also checked whether the presence of foreign operations might affect the structure of CEO compensation. For each company, we constructed a dummy variable, multinationality, to indicate when the firm has foreign operations and we re-estimated the pay-performance regressions for the subsample "Multinational companies" and "Local companies" (Table 7). The results show interesting differences between the two groups of firms. First, we find that within the subsample of multinational companies, there is no difference in pay-for-performance sensitivity between regulated and unregulated firms. Moreover, whereas CEO tenure confirms its positive influence and State Ownership confirms its negative effect on CEO pay as in Table 5, we notice that firm size is insignificant in this sample, probably because all multinational firms are similarly large. In contrast, we report interesting differences within the sub-sample of local energy companies because both firm size and State Ownership positively affects the level of CEO pay, whereas the difference in the sensitivity of pay to performance for regulated and deregulated firms returns is statistically significant. Finally, we notice the negative coefficient on the market capitalization to GDP ratio, which suggests that, all else being equal, CEO pay in energy firms is larger when financial markets are less developed. Overall, these results confirm that energy managers "enjoy the quiet life" (Bertrand and Mullainathan 2003) in local, state-owned regulated firms, in which both competitive pressure and the financial market's discipline appear weaker.

In Table 8, we estimate the augmented model (3), in which we include the country-level time-invariant variables to control for differences in the national governance systems. We thus include Common Law, Anti Director Index and Enforcement Index to capture the differences in national institutions. We add the variable Disclosure to control for the strength of disclosure requirements. The results in Table 8 show that Common Law enters with a positive sign and is statistically significant, which indicates that CEO compensation is higher in common law countries, although the negative sign on the Anti Director index indicates that, ceteris paribus, where the protection of minority shareholders is stronger, CEO compensation is lower. Turning to the other variables, we find a positive coefficient on the Enforcement Index, thus denoting countries in which the law is more effectively enforced, whereas the negative sign on Disclosure suggests that CEO compensation is lower in countries with stronger disclosure requirements.

\footnotetext{
${ }^{8}$ We also estimated the same specification on the subsample of gas utilities, although this group of firms is smaller than the subsample of electric firms. The results are qualitatively similar. We do not report them for reasons of space, but they are available on request.
} 
Finally, we notice that the key result on the lower pay-performance sensitivity within regulated energy firms survives when accounting for all of these countryspecific characteristics of the national governance system.

\section{Conclusions}

This paper studies the effects of incentive mechanisms provided by economic regulation and corporate governance in European energy firms in the period 2000-2011. Our results show that managerial incentives differ across regulated and unregulated firms. Specifically, we find that pay-for-performance sensitivity in regulated transmission and distribution operators is lower than in unregulated generation firms. This evidence is robust across different measures of firm performance and suggests that incentive compensation interacts with economic regulation.

This difference could be explained by the different intensity of market competition. Managers in regulated firms (transmission service operators or distribution service operators) perform in a less competitive environment, where profitability targets are more or less set by regulators. For this reason, shareholders may be reluctant to bear the agency costs that are associated with high monetary incentives tied to firm performance. Alternatively, the regulatory environment might impose political constraints on CEO compensation, as suggested by Joskow et al. (1996). Indeed, in many regulated utilities, particularly those that are statecontrolled, directors are either politicians or appointed by politicians who are subject to public pressure (Faccio 2006). Therefore, to avoid public concern about excessive CEO compensation, CEO remuneration is expected to be lower and less tied to firm profitability.

Controlling for all of these factors, our results survive. Our key findings do not change if we control for different national corporate governance attributes (investor protection, legal origin, disclosure requirement and enforcement of the contracts).

The difference in pay-for-performance sensitivity between regulated and unregulated firms suggests that incentive compensation is a weaker incentive mechanism in companies operating in regulated and less competitive markets.

\section{Appendix 1}

See Table 9. 
Table 9 Energy firms by country and regulatory status

\begin{tabular}{|c|c|c|c|}
\hline Country & Company name & Deregulated & Regulated \\
\hline Austria & Verbund & & $\mathrm{X}$ \\
\hline Belgium & Elia System Operator & & $X$ \\
\hline Finland & Fortum & & $\mathrm{X}$ \\
\hline \multirow[t]{9}{*}{ France } & Areva & $\mathrm{X}$ & \\
\hline & Electricité de France & & $\mathrm{X}$ \\
\hline & EDF Energies Nouvelles & $\mathrm{X}$ & \\
\hline & Electricité de Strasburg & & $\mathrm{X}$ \\
\hline & Sechilienne-Sidec & $\mathrm{X}$ & \\
\hline & Theolia & $\mathrm{X}$ & \\
\hline & Veolia & $\mathrm{X}$ & \\
\hline & Gaz de France & & $\mathrm{X}$ \\
\hline & GDF Suez & & $X$ \\
\hline \multirow[t]{6}{*}{ Germany } & E.On & & $\mathrm{X}$ \\
\hline & En.BW & & $\mathrm{X}$ \\
\hline & MVV Energie & & $\mathrm{X}$ \\
\hline & RWE & & $\mathrm{X}$ \\
\hline & Vattenfall & $\mathrm{X}$ & \\
\hline & Mainova & & $\mathrm{X}$ \\
\hline \multirow[t]{13}{*}{ Italy } & Edison & & $X$ \\
\hline & $\mathrm{A} 2 \mathrm{~A}$ & & $\mathrm{X}$ \\
\hline & Hera & & $\mathrm{X}$ \\
\hline & Enel & & $\mathrm{X}$ \\
\hline & ENI & $\mathrm{X}$ & \\
\hline & Terna & & $\mathrm{X}$ \\
\hline & Acea & & $\mathrm{X}$ \\
\hline & Iride & & $X$ \\
\hline & Acegas-Aps & & $\mathrm{X}$ \\
\hline & ACSM & & $\mathrm{X}$ \\
\hline & Ascopiave & & $\mathrm{X}$ \\
\hline & Enia & & $\mathrm{X}$ \\
\hline & Snam & & $\mathrm{X}$ \\
\hline Norway & Hafslund ASA & & $\mathrm{X}$ \\
\hline \multirow[t]{2}{*}{ Poland } & PGE Polska Group Energetyczna & & $\mathrm{X}$ \\
\hline & ENEA & & $\mathrm{X}$ \\
\hline Portugal & Energias de Portugal & & $\mathrm{X}$ \\
\hline \multirow[t]{5}{*}{ Spain } & Endesa & & $\mathrm{X}$ \\
\hline & Gas Natural & & $\mathrm{X}$ \\
\hline & Iberdola & & $\mathrm{X}$ \\
\hline & Red Electrica Corporacion & & $\mathrm{X}$ \\
\hline & Enagas & & $\mathrm{X}$ \\
\hline
\end{tabular}


Table 9 continued

\begin{tabular}{|c|c|c|c|}
\hline Country & Company name & Deregulated & Regulated \\
\hline \multirow[t]{5}{*}{ Switzerland } & Società Elettrica Sopracenerina & & $X$ \\
\hline & BKW FMV & & $X$ \\
\hline & Romande Energie Holding & & $\mathrm{X}$ \\
\hline & Alpiq Holding & & $X$ \\
\hline & Repower & & $X$ \\
\hline \multirow[t]{17}{*}{ UK } & Viridian & & $\mathrm{X}$ \\
\hline & British Energy & & $X$ \\
\hline & BG Group & $\mathrm{X}$ & $X$ \\
\hline & Drax Group & $X$ & $\mathrm{X}$ \\
\hline & Helius Energy & $X$ & $\mathrm{X}$ \\
\hline & International & $\mathrm{X}$ & \\
\hline & Power & & $\mathrm{X}$ \\
\hline & Jersey Electricity & $X$ & \\
\hline & Novera Energy & $X$ & \\
\hline & Renewable Energy & $X$ & \\
\hline & Generation Ltd & $\mathrm{X}$ & \\
\hline & Renewable Energy & & $\mathrm{X}$ \\
\hline & Holding & $X$ & \\
\hline & SSE & $X$ & \\
\hline & Centrica & & $X$ \\
\hline & Igas Energy & $X$ & \\
\hline & National Grid & $X$ & \\
\hline
\end{tabular}

\section{Appendix 2}

See Table 10. 


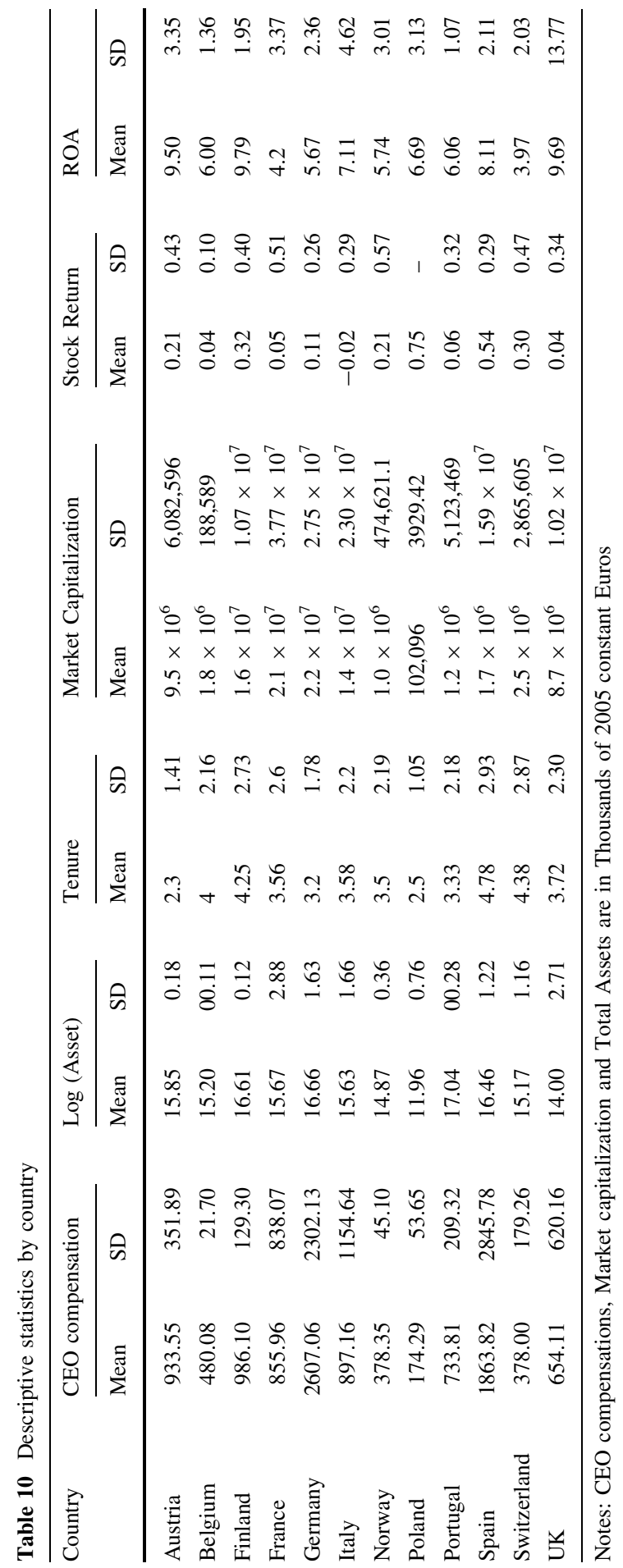




\section{References}

Abowd, J. M., \& Bognanno, M. L. (1995). International differences in executive and managerial compensation. In R. B. Freeman \& L. F. Katz (Eds.), Differences and changes in wage structures (pp. 67-104). Chicago: University of Chicago Press.

Adams, R. B., \& Ferreira, D. (2012). Regulatory Pressure and Bank Directors' Incentives to Attend Board Meetings. International Review of Finance, 12(1), 227-248.

Adams, R., \& Mehran, H. (2003). Is corporate governance different for bank holding companies? FRBNY Economic Policy Review, 9, 123-142.

Agrawal, A., \& Knoeber, C. R. (1996). Firm Performance and Mechanisms to Control Agency Problems between Managers and Shareholders. The Journal of Financial and Quantitative Analysis, 31(3), 377-397.

Armstrong, M., \& Sappington, D. E. M. (2006). Regulation, competition and liberalization. Journal of Economic Literature, XLIV, 325-366.

Aslan H., \& Kumar P. (2014) National governance bundles and agency costs: A cross-country analysis. Corporate Governance: An International Review, 22, 230-251.

Baker, G. P., \& Hall, B. J. (2004). CEO incentives and firm size. Journal of Labor Economics, 22(4), 767-798.

Barontini, R., \& Bozzi, S. (2011). CEO compensation and firm performance in family firms. The Journal of Management and Governance, 15(1), 59-89.

Bebchuk, L. A., \& Fried, J. M. (2004). Pay without performance: The unfulfilled promise of executive compensation. Cambridge: Harvard University Press.

Becher, D. A., \& Frye, M. B. (2011). Does regulation substitute or complement governance? Journal of Banking \& Finance, 35, 736-751.

Beiner, S., Schmid, M. M., \& Wanzenried, G. (2011). Product market competition, managerial incentives and firm valuation. European Financial Management, 17(2), 331-366.

Bender, R. (2003). How executive directors' remuneration is determined in two FTSE 350 Utilities. Corporate Governance: An International Review, 11(3), 206-217.

Bertrand, M., \& Mullainathan, S. (2003). Enjoying the quiet life? Corporate governance and managerial preferences. Journal of Political Economy, 111(5), 1043-1075.

Booth, J. R., Cornett, M. M., \& Tehranian, H. (2002). Boards of directors, ownership, and regulation. Journal of Banking \& Finance, 26, 1973-1996.

Bortolotti, B., Cambini, C., Rondi, L., \& Spiegel, Y. (2011). Capital structure and regulation: Do ownership and regulatory independent matter? Journal of Economics \& Management Strategy, 20(2), 517-564.

Bushman, R. M., Indjejikian, R. J., \& Smith, A. (1996). CEO compensation: The role of individual performance evaluation. Journal of Accounting and Economics, 21, 161-193.

Cambini, C., \& Rondi, L. (2010). Incentive regulation and investment: evidence from European energy utilities. Journal of Regulatory Economics, 38(1), 1-26.

Cambini, C., Rondi, L., \& De Masi, S. (2015). Incentive compensation: Does regulation matter? Corporate Governance: An International Review, 3(4), 378-395.

Cambini, C., Rondi, L., \& Spiegel, Y. (2012). Investment and the strategic role of capital structure in regulated industries: Theory and evidence. In J. Harrington \& Y. Katsoulacos (Eds.), Recent advances in the analysis of competition policy and regulation. Cheltenham: E. Elgar Publishing.

Carroll, T. M., \& Ciscel, D. H. (1982). The effects of regulation on executive compensation. Review of Economics and Statistics, 64, 505-509.

Cheng, I., Hong, H., \& Scheinkman, J. (2015). Yesterday's heroes: Compensation and creative risktaking. Journal of Finance, 70(2), 839-879.

Claessens, S., Djankov, S., \& Lang, L. (2000). The separation of ownership and control in East Asian Corporations. Journal of Financial Economics, 58, 81-112.

Conway, P., \& Nicoletti, G. (2006). Product market regulation in the non manufacturing sectors of OECD countries: Measurement and highlights. OECD Economics Department Working Paper $\mathrm{n}$. 530, OECD, Paris.

Conyon, M., \& Murphy, K. (2000). The prince and the Pauper? CEO pay in the United States and United Kingdom. Economic Journal, 110, 640-671.

Conyon, M., Fernandes, N., Ferreira, M., Matos, P., \& Murphy, K. J. (2013). The executive compensation controversy: a transatlantic analysis. In T. Boeri, C. Lucifora \& K. Murphy (Eds.), Executive 
remuneration and employee performance-related pay: a transatlantic perspective. Oxford: Oxford University Press.

Croci, E., Gonenc, H., \& Ozkan, N. (2012). CEO compensation, family control and institutional investor in continental Europe. Journal of Banking \& Finance, 36(12), 3318-3335.

Demsetz, H. (1983). The structure of ownership and the theory of the firm. Journal of Law and Economics, 26, 375-390.

Djankov, S., Hart, O., McLiesh, C., \& Shleifer, A. (2008). Debt enforcement around the world. Journal of Political Economy, 116, 1105-1149.

Faccio, M. (2006). Politically connected firms. American Economic Review, 96(1), 369-386.

Faccio, M., \& Lang, L. H. P. (2002). The ultimate ownership of Western European Corporations. Journal of Financial Economics, 65, 365-395.

Fama, E. F., \& Jensen, M. C. (1983). Separation of ownership and control. Journal of Law and Economics, 26, 301-325.

Fernandes, N., Ferreira, M. A., Matos, P., \& Murphy, K. J. (2013). Are U.S. CEOs paid more? New international evidence. Review of Financial Studies, 26, 267-323.

Frydman, C. (2007). The evolution of the market for corporate executives across the twentieth century. Journal of Economic History, 67, 488-492.

Frydman, C. (2009). Learning from the past: Trends in executive compensation over the twentieth century. CESifo Economic Studies., 55, 458-481.

Frydman, C., \& Saks, R. E. (2010). Executive compensation: A new view from a long-term perspective, 1936-2005. Review of Financial Studies., 23, 2099-2138.

Gibbons, R., \& Murphy, K. J. (1990). Relative performance evaluation for chief executive officers. Industrial Labor Relation Review, 43(3), 30S-51S.

Giroud, X., \& Mueller, H. (2010). Does corporate governance matter in competitive industries? Journal of Financial Economics, 95, 312-331.

Goergen, M., \& Renneboog, L. (2011). Managerial compensation. Journal of Corporate Finance, 17(4), 1068-1077.

Guay, W. R. (1999). The sensitivity of CEO wealth to equity risk: An analysis of the magnitude and determinants. Journal of Financial Economics, 53(1), 43-71.

Hadlock, C. J., Scott Lee, D., \& Parrino, R. (2002). Chief executive officer careers in regulated environments: Evidence from electric and gas utilities. Journal of Law and Economics, 45(2), 535-563.

Hall, B., \& Liebman, J. (1998). Are CEOs really paid like bureaucrats? Quarterly Journal of Economics, 113, 653-691.

Hart, O. D. (1983). The market mechanism as an incentive scheme. Bell Journal of Economics, 14, 366-382.

Hart, O., Shleifer, A., \& Vishny, R. (1997). The proper scope of government: Theory and application to prisons. The Quarterly Journal of Economics, 112(4), 1091-1126.

Hermalin, B. E. (1992). The effects of competition on executive behavior. Rand Journal of Economics, 23, 350-365.

Holmström, B. R., \& Tirole, J. (1989). The theory of the firm. In R. Schmalensee \& R. D. Willig (Eds.), Handbook of industrial organization (Vol. I). Amsterdam: Elsevier.

Hubbard, R. G., \& Palia, D. (1995). Executive pay and performance Evidence from the U.S. banking industry. Journal of Financial Economics, 39, 105-130.

Jensen, M. C., \& Meckling, W. H. (1976). Theory of the firm: Managerial behavior, agency costs and ownership structure. Journal of Financial Economics, 3, 305-360.

Jensen, M. C., \& Murphy, K. J. (1990). Performance pay and top-management incentives. Journal of Political Economy, 98, 225-264.

Joskow, P., Rose, N., \& Shepard, A. (1993). Regulatory constraints on CEO compensation. Booking papers on economic activity. Microeconomics, 1, 1-72.

Joskow, P., Rose, N., \& Wolfram, C. (1996). Political constraints on executive compensation: Evidence from the electric utility industry. Rand Journal of Economics, 27(1), 165-182.

Kumar, P., \& Zattoni, A. (2013). How much do country-level or firm level variables matter in corporate governance studies? Corporate Governance: An International Review, 21, 199-200.

La Porta, R., Lopez-de-Silanes, F., \& Shleifer, A. (1999). Corporate ownership around the world. Journal of Finance, 54, 471-518.

Martynova, M., \& Renneboog, L. (2011). Evidence on the international evolution and convergence of corporate governance regulations. Journal of Corporate Finance, 17, 1531-1557. 
Murphy, K. J. (1985). Corporate performance and managerial remuneration: An empirical analysis. Journal of Accounting and Economics, 7(1), 11-42.

Murphy, K. J. (1999). Executive compensation. In: O. Ashenfelter \& D. Card (Eds.), Handbook of labor economics $\left(1^{\text {st }}\right.$ ed., Vol. 3, pp. 2485-2563).

Murphy, K. J. (2012). Executive compensation: Where we are, and how we got there. In G. Constantinides, M. Harris, \& R. Stulz (Eds.), Handbook of the economics of finance. Amsterdam: Elsevier/North-Holland.

Muslu, V. (2010). Executive directors, pay disclosures, and incentive compensation in large European companies. Journal of Accounting, Auditing, and Finance, 25, 569-605.

Nickell, S. J. (1996). Competition and corporate performance. Journal of Political Economy, 104, $724-746$.

Palia, D. (2000). The impact of regulation on CEO labor market. RAND Journal of Economics.

Schmidt, K. (1997). Managerial incentives and product market competition. Review of Economic Studies, 64, 191-213.

Shleifer, A., \& Vishny, R. W. (1997). A survey of corporate governance. Journal of Finance, 52, $737-783$.

Tricker, B. (2012). Corporate governance: Principles, policies and practices. Oxford: Oxford University Press.

Yermack, D. (1995). Do corporations award CEO stock options effectively? Journal of Financial Economics, 39(23), 237-269. 